Abstracta Iranica Abstracta Iranica

Revue bibliographique pour le domaine irano-aryen

Volume 30 | 2010

Comptes rendus des publications de 2007

\title{
« Weitere ägyptische Amulette aus Palästina/ \\ Israel ». ZDPV, 123, 2007, pp. 93-132.
}

\section{Astrid Nunn}

\section{(2) OpenEdition}

1 Journals

\section{Édition électronique}

URL : http://journals.openedition.org/abstractairanica/37649

DOI : 10.4000/abstractairanica.37649

ISSN : 1961-960X

Éditeur :

CNRS (UMR 7528 Mondes iraniens et indiens), Éditions de l'IFRI

\section{Édition imprimée}

Date de publication : 8 avril 2010

ISSN : 0240-8910

\section{Référence électronique}

Astrid Nunn, « "Weitere ägyptische Amulette aus Palästina/Israel ». ZDPV, 123, 2007, pp. 93-132. », Abstracta Iranica [En ligne], Volume 30 | 2010, document 75, mis en ligne le 08 avril 2010, consulté le 26 septembre 2020. URL : http://journals.openedition.org/abstractairanica/37649; DOI : https:// doi.org/10.4000/abstractairanica.37649

Ce document a été généré automatiquement le 26 septembre 2020.

Tous droits réservés 


\section{« Weitere ägyptische Amulette aus Palästina/Israel ». ZDPV, 123, 2007, pp. 93-132.}

\section{Astrid Nunn}

1 L'A. est devenu le spécialiste incontesté des amulettes trouvées en Israël et Palestine dont il a publié 4 volumes depuis le lancement du projet en 1991 (1994, 2002, 2003 et 2006, cf. c.r. pour l'année 2006). Cet article, plus modeste, présente 33 pièces - aucune n'avait été publiée -, dont 28 appartiennent à la collection du Musée BIBLE + ORIENT de l'Université de Fribourg/Suisse, et 5 proviennent de fouilles et sont conservées en Israël. L'article est conçu de la même manière que les publications précédentes. La grande majorité des amulettes date du Fer I-II, certaines de l'époque achéménide. Le nombre de types est surtout restreint à l'oeil Udjat, à Bes et aux nains (patèques).

\section{INDEX}

Thèmes : 3.2.2. Pré-Achéménides et Achéménides

\section{AUTEURS}

ASTRID NUNN

Université de Munich 